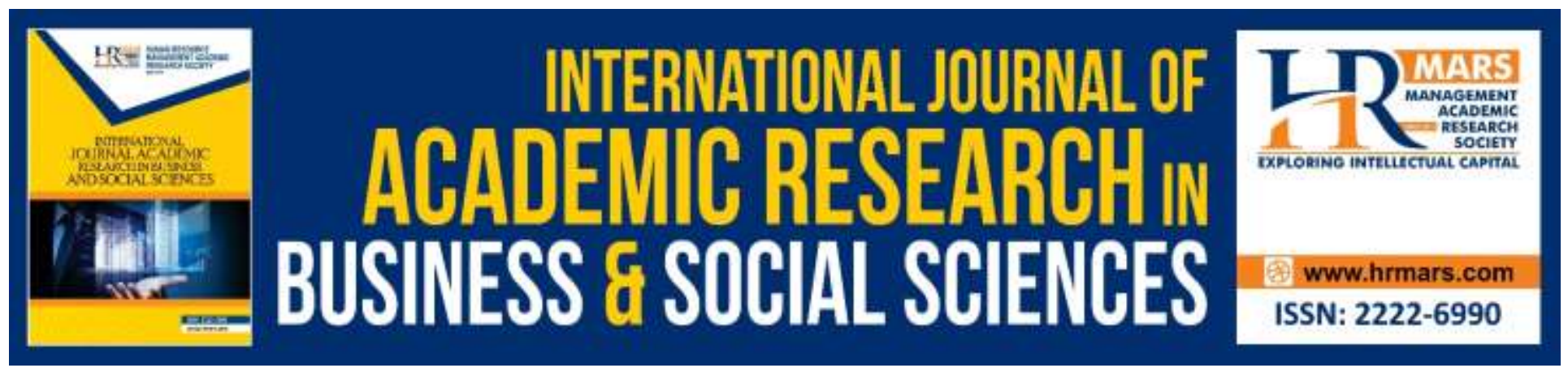

\title{
Barriers to Women's Advancement in the Malaysian Private Enterprises
}

Samuel, R., Omar, R., \& Hassian, U.

To Link this Article: http://dx.doi.org/10.6007/IJARBSS/v10-i13/6884

DOI:10.6007/IJARBSS/v10-i13/6884

Received: 20 December 2019, Revised: 04 January 2020, Accepted: 20 January 2020

Published Online: 10 February 2020

In-Text Citation: (Samuel et al., 2020)

To Cite this Article: Samuel, R., Omar, R., \& Hassian, U. (2020). Barriers to Women's Advancement in the Malaysian Private Enterprises. International Journal of Academic Research in Business and Social Sciences, 10(13), 11-19.

\section{Copyright: (c) 2020 The Author(s)}

Published by Human Resource Management Academic Research Society (www.hrmars.com)

This article is published under the Creative Commons Attribution (CC BY 4.0) license. Anyone may reproduce, distribute, translate and create derivative works of this article (for both commercial and non-commercial purposes), subject to full attribution to the original publication and authors. The full terms of this license may be seen

at: $\underline{\text { http://creativecommons.org/licences/by/4.0/legalcode }}$

Special Issue: Upstream Research in Business and Management: Towards Socio-Economic Prosperity, 2020, Pg. 11 - 19

Full Terms \& Conditions of access and use can be found at http://hrmars.com/index.php/pages/detail/publication-ethics 


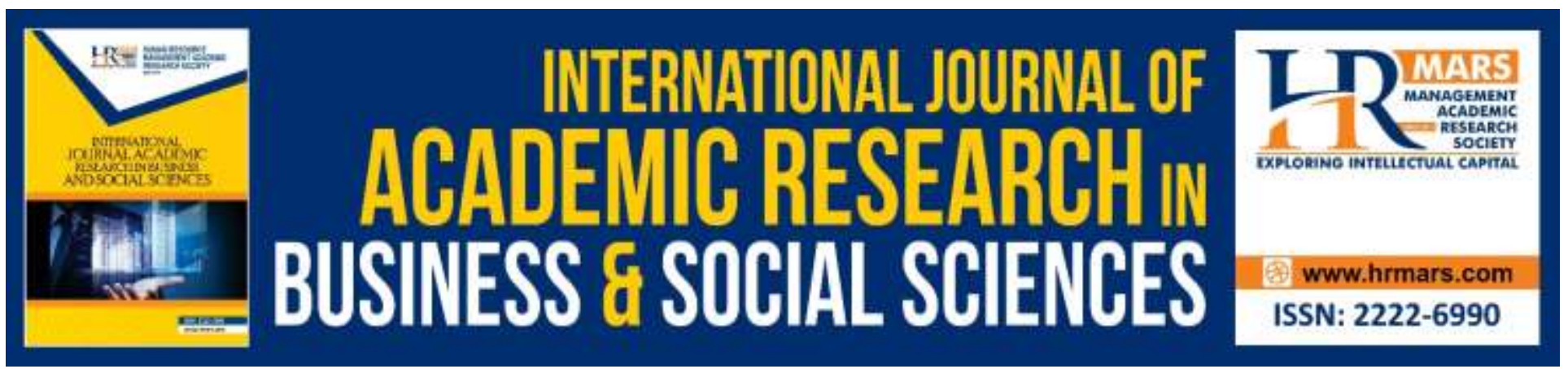

\title{
Barriers to Women's Advancement in the Malaysian Private Enterprises
}

\author{
Samuel, R., Omar, R., \& Hassian, U.
}

Faculty of Business Management, UiTM Melaka

\begin{abstract}
As of late, participation of women in the Malaysian workplaces is given high priority. Compared to other South East Asian countries, Malaysia still has low numbers of female participation at the workplace despite various initiatives by the government. In addition, retention of women is another issue which can be related to the issue of women's advancement in the workplace. Though research has shown that gender bias practices are reducing, challenges in different shapes and forms still remain. This study was carried out among two groups of women; one group that is still actively employed and another group which has left the workplace, after some years of being actively employed. Both groups of women held middle management positions. The findings show that many barriers at the workplace still exist. Explicit barriers such as the glass ceiling and lack of mentoring are still hindering women from progressing in the workplaces. In addition, gender stereotyping and discrimination still exists. The respondents were confident that women have what is needed to be successful at the workplace; however, they were victimized by both implicit and explicit barriers
\end{abstract}

Keywords: Women, Advancement, Barriers

\section{Introduction}

Gender differences in professional workforce participation have been given scant attention in Malaysia. The stature of women has become a primary objective of the 6th Malaysia Plan (1991 1995), where a special fund for the development of women became a significant and integral step towards empowering women in Malaysia. This Plan promised "to integrate women as equal partners in nation-building" and this desire to include women continued to the Ninth Malaysia Plan (20062010), which pledged "to provide an enabling environment to ensure more effective participation of women in national development". However, progress has remained slow.

The Tenth Malaysia Plan (2011-2015) stated that steps will be taken to increase the participation of women at all levels in both the public and private sectors, including entrepreneurial ventures. This plan proposed to review existing laws and related regulations to create a more conducive environment that encourages greater female participation in the workforce. The $10^{\text {th }}$ Malaysia Plan also urged the private sector to increase the participation of women, especially in senior positions, such as Chief Executive Officers and members of Board of Directors. One of the key 
INTERNATIONAL JOURNAL OF ACADEMIC RESEARCH IN BUSINESS AND SOCIAL SCIENCES

Vol. 10, No. 13, Special Issue: Upstream Research in Business and Management: Towards Socio-Economic Prosperity. 2020, E-ISSN: 2222-6990 @ 2020 HRMARS

priorities of the government's $11^{\text {th }}$ Malaysia Plan is to improve the female labour participation rate by 5 percentage points to 59 percent by 2020. For this to happen, education is key. Thus, although plans to increase and integrate women into the workforce have been in place since 1990s, nothing much has changed. Women's participation in the labour force has remained mostly static, in 1980, the participation was $23.4 \%$ and twenty-four years later, in 2004, the participation of women in the workforce was only $25.4 \%$ (an increase of a dismal 2\%). Female Labor Force Participation Rate (LFPR) rose 0.2 percentage points to 54.3 percent in 2016. The participation of male LFPR was 80.2 percent for the same year; dropping 0.4 percentage points compared to 2015. As a whole, however, male LFPR was still higher than female LFPR (Department of Statistics, 2017).

Only $46 \%$ of Malaysian women are in the workforce compared to 60 percent in Singapore and 70 percent in Thailand. Further, there is a decrease in the number of women in higher job positions especially in the professional workforce (Izharuddin et al., 2013). Not only the participation of women in the workforce is an issue, their advancement is another major area of concern. In 2011, the Malaysian government announced a target for the corporate sector to push for women to represent $30 \%$ of decision-making positions by the end of 2016. In 2013, women made up $26 \%$ of senior management and 13\% Board of Directors (Thornton, 2013). In June 2016, women accounted for only $15.2 \%$ of director positions in the top 100 listed companies on Bursa Malaysia (Merican \& Ghani, 2017). Research has shown that various structural barriers inhibit women from full engagement with the workforce (Inglehart \& Norris, 2003). These barriers include sex role stereotypes, gender discrimination in employment and "brain-drain" (the exodus of women from white collar workforce to stay at home to care for the family).

\section{Literature Review}

When there are more women in top management positions, it is discovered that less risky decisions are made, less engagement in theft, fraud and corruptions are discovered and organizations are better protected from failure (Davidson \& Burke, 2011). According to the UNDP, an increase in the number of women in the workforce would boost Malaysia's GDP by $2.9 \%$ (UNDP, 2010). Though positive signs exist, women still face numerous challenges and barriers, making it difficult to have satisfying careers in large organizations (Eagly \& Carli, 2007; Mainiero \& Sullivan, 2006). The structural discrimination theory provides support in explaining the differences between males and females with regard to their involvement in the workforce (Etzkowitz et al., 2000; Rosser, 2004). Over the years, a number of explanations have emerged to identify the reasons for the gap between males and females in terms of professional workforce participation. Lower levels of workforce participation for women especially professional women, could reflect various structural barriers that inhibit them from full engagement with the workforce (Inglehart \& Norris, 2003). These barriers include sex role stereotypes, and gender discrimination in employment. A second explanation is that gender differences in female and male life courses (parenthood and work-life balance) have implications for work-force participation. The different ways in which this event is managed lead females and males to make very different decisions regarding workforce participation, with these decisions contributing to the gender gap (Anderson et al., 2002; O'Dorchai, 2008). This has contributed to what is commonly known as the "brain drain" of women (where qualified women leave the workforce to stay at home to care for the family) (Izharuddin et al., 2013). 
INTERNATIONAL JOURNAL OF ACADEMIC RESEARCH IN BUSINESS AND SOCIAL SCIENCES

Vol. 10, No. 13, Special Issue: Upstream Research in Business and Management: Towards Socio-Economic Prosperity. 2020, E-ISSN: 2222-6990 @ 2020 HRMARS

Evidence suggests that there has been a consistent gender gap in workforce participation with men being more likely than women to be engaged in the workforce (Molina \& Montuenga, 2009; The World Bank, 2012). Inequalities between female and male workforce participation across a number of developed nations still exist (The World Bank, 2012). Though the existence of this gap is recognized, scant attention has been given to reduce and further eliminate this gap (Gibb et al, 2013). A report by the International Labor Organization using data from over 200 countries suggests that between 1980 and 2008, the gender gap in workforce participation narrowed only slightly, from 32 to $26 \%$ points (Elder, 2010).

Other than various barriers at the workplace, there also exists gender wage gap, where women are paid lesser than men (Ismail, R., \& Jajri, I., 2012). It was discovered that the wage differences in the blue collared jobs can be explained by wage-related characteristics, such as experience, education and hours of work. However, in the white collared and managerial group, though women surpassed men in all wage-related characteristics, men still received higher wages (Fernandez, 2009). It is a fact that there are more women in universities than men in Malaysia. In 2015, close to 55 percent of higher education intakes (public and private universities, community colleges, and polytechnics) were dominated by females at 280,296 versus males at 230,858 . The same year also saw 169,198 females successfully graduating from higher education versus males at 120,596 . Unfortunately, significant gains by women in tertiary education have not translated into better labour market outcomes. Aside from the teaching industry, women are not seen to be participating dominantly in the workforce nor as leaders in the corporate, legal, academic, economic or the political scene in proportion to the educational gain demonstrated (Faizli, 2017). The access to education has not translated into proportionate economic and political opportunities and outcomes for Malaysian women because of various barriers.

\section{Method}

This paper examines the perception of two groups of women on barriers to career advancement and retention. One group consists of women who are currently working and the second group, women who used to be part of the workforce but have since left the workforce. In view of the above, a survey was carried out to determine whether barriers do exist at the workplace and how women perceive these barriers. The respondents were identified through purposive sampling to ensure that they were women who were still employed or women who were employed but left the workplace due to their need to take care of children/ aging parents, to name a few. A total of 117 women responded to this survey; 40 had since left the workplace and 77 were still employed. The respondents were/still are in the middle management and above. The statements in the questionnaire were adapted from Wellington, Kropf and Gerkovich (2003); Sahid, Noordin, \& Sani (2018). Respondents were asked to respond whether they agreed or disagreed with the eleven statements in the questionnaire. The responses were then analyzed to determine the perceptions of the respondents on the issue of barriers at the workplace.

\section{Results and Discussion}

Table 1 presents the frequency analysis of the responses from both the groups of women. Though the analysis is simple in nature, the implications of the findings are interesting. It is interesting to 
INTERNATIONAL JOURNAL OF ACADEMIC RESEARCH IN BUSINESS AND SOCIAL SCIENCES

Vol. 10, No. 13, Special Issue: Upstream Research in Business and Management: Towards Socio-Economic Prosperity. 2020, E-ISSN: 2222-6990 @ 2020 HRMARS

examine the various statements that both the groups agree to, the barriers that are considered a problem only by the non-working women and the statements that both groups disagreed to.

TABLE 1: Barriers to career advancement and retention of women

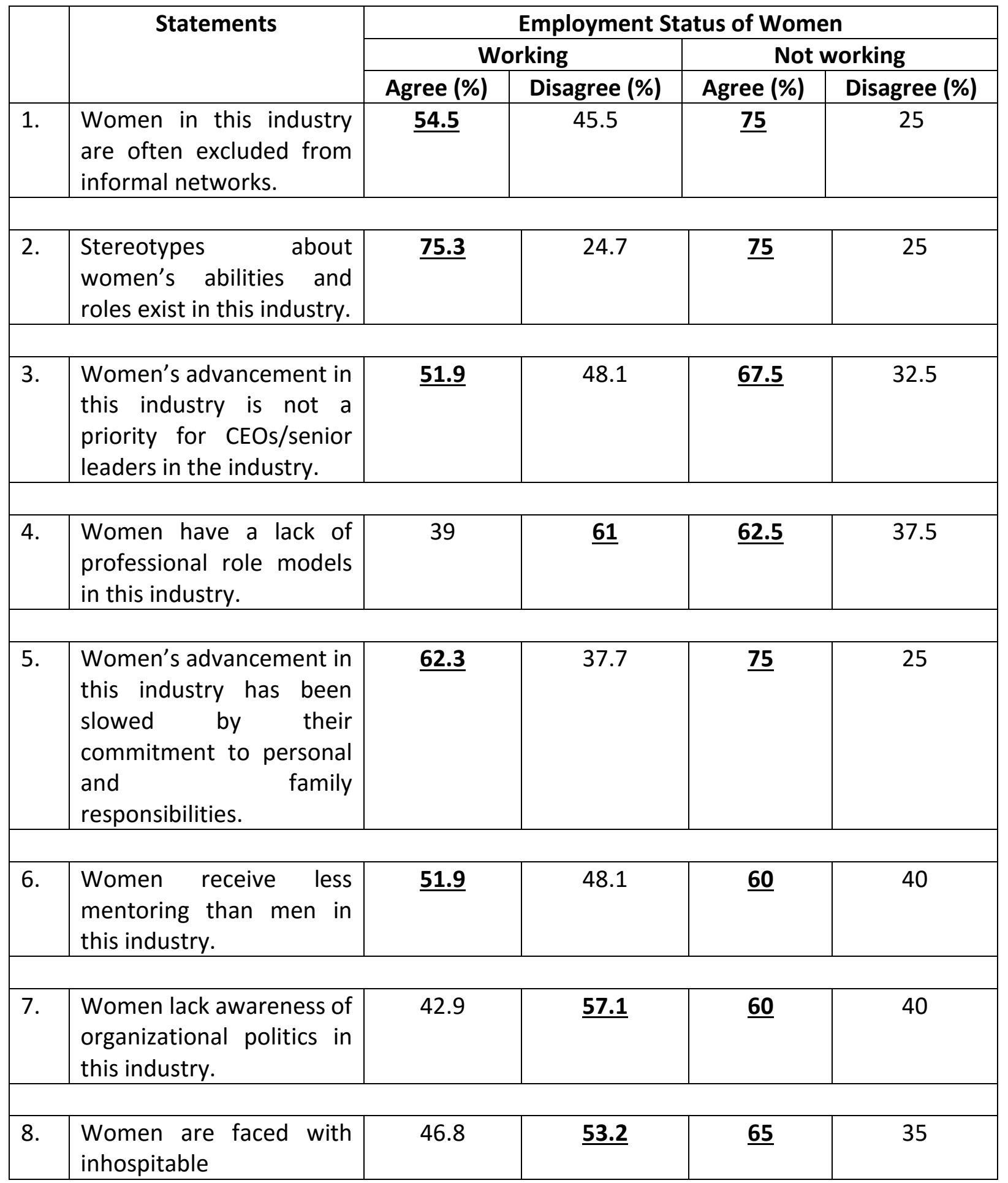


INTERNATIONAL JOURNAL OF ACADEMIC RESEARCH IN BUSINESS AND SOCIAL SCIENCES

Vol. 10, No. 13, Special Issue: Upstream Research in Business and Management: Towards Socio-Economic Prosperity. 2020, E-ISSN: 2222-6990 @ 2020 HRMARS

\begin{tabular}{|c|c|c|c|c|c|}
\hline & $\begin{array}{l}\text { organizational culture in } \\
\text { this industry. }\end{array}$ & & & & \\
\hline 9. & $\begin{array}{l}\text { Women do not get } \\
\text { enough opportunities for } \\
\text { challenging assignments } \\
\text { in this industry. }\end{array}$ & 48.1 & $\underline{51.9}$ & $\underline{60}$ & 40 \\
\hline 10. & $\begin{array}{l}\text { Women have less of a } \\
\text { desire to advance to a } \\
\text { senior level in this } \\
\text { industry than men. }\end{array}$ & 48.1 & $\underline{51.9}$ & 45 & $\underline{55}$ \\
\hline 11. & $\begin{array}{l}\text { Women lack effective } \\
\text { leadership styles for this } \\
\text { industry. }\end{array}$ & 35.1 & 64.9 & 30 & $\underline{70}$ \\
\hline
\end{tabular}

Both the groups of women agreed that the glass ceiling and structural barriers still exist at the Malaysian workplaces (Statements 1, 2, 3, 5 and 6). Despite women progressing in education and the country becoming more developed, and despite the policies by the government to support women's entry and retention at the workplace, barriers such as stereotyping, lack of mentoring and being excluded from networks (which used to be known as "the boys network') still exist. The case in Malaysia is different from what was found by Zimmerman (2016). She found explicit gender bias had largely disappeared due to tougher legislation and the increased focus on diversity issues. On the other hand, Schwanke (2013); Iyem, Ozturk, Yildiz (2018) found that there are three major barriers in the workplace. They are, first, societal and corporate structures. These structures would include those created by society and the corporate world, such as expectations of women and their roles and the glass ceiling which is invisible yet existing in most organizations. The second barrier is the perceptions of the leadership. In many industries, there are leaders who still perceive that women are weak, or unable to carry out certain roles, or that women are to play only the "caring" roles in organizations. This phenomenon is also known as "stereotype confirmation" where the leaders confirm their stereotypes while filtering out all other examples (Global Network Perspectives, 2017). The third barrier is discrimination. Gender based discrimination exists in many industries and in positions of power, but mainly in the fields of Science, Technology, Engineering and Mathematics. Gender stereotypes were prevalent in male-dominated working culture (Kurshitashvili, 2018).

A higher proportion of the women who had left the workplace and were currently not working attributed the problems of retention and advancement of women to the culture of the workplace. They felt that women were not given challenging tasks/ assignments, unaware of organizational politics and also lacked professional role models (Statements 4, 7, 8 and 9). A study by UN Women found that workplace culture is a main factor that hinders women's participation in the workplace especially in the Middle East and North Africa region (Jaber, 2017; Chrysoula, 2014). Hamel (2009) found that when women perceive that they are treated unfairly, they will do one of the following: 
INTERNATIONAL JOURNAL OF ACADEMIC RESEARCH IN BUSINESS AND SOCIAL SCIENCES

Vol. 10, No. 13, Special Issue: Upstream Research in Business and Management: Towards Socio-Economic Prosperity. 2020, E-ISSN: 2222-6990 @ 2020 HRMARS

leave quietly, leave while voicing objections, remain at work and be silent or remain at work and raise awareness. This group of women could be those who left the workplace because they perceived certain barriers to their advancement.

Interestingly, both groups of women disagreed that the lack of advancement of women at the workplace was due to their own inabilities or weaknesses (Statements 10 and 11). This was also found to be true by Lang (2012). She stated that the perception that women do not advance because they shrink from opportunities, a term known as "ambition gap" is a myth.

\section{Conclusion}

In conclusion, barriers at the workplace for women still exist. If Malaysia is serious in pursuing the agenda on empowering women through participation and advancement at the workplace, then there must be concerted efforts to eliminate these existing barriers. Whether it is the glass ceiling, glass walls or sticky floors, there must be a stop to any forms of discrimination towards women.

\section{Acknowledgements}

The authors gratefully acknowledge the help of the Ministry of Higher Education (KPT)TI) of Malaysia in providing the Fundamental Research Grant Scheme (FRGS) (600-IRMI/FRGS 5/3 36/2016) and Institute of Research Management and Innovation, UiTM Malaysia. The authors are also thankful to all the respondents from the various private enterprises who helped in this survey.

\section{References}

Anderson, D. J., Binder, M., \& Krause, K. (2002). The motherhood wage penalty: Which mothers pay it and why? The American Economic Review, 92 (2), 354-358.

Chrysoula, P. (2014). Recording Literacy Practices of Monolingual and Bilingual Infants. Multilingual Academic Journal of Education and Social Sciences, 2(2), 86-113.

Davidson, M. J., \& Burke, R. J. (2011). Women in Management: Worldwide Progress and Prospects. Surrey: Gower.

Department of Statistics. (2017). Labor Force Survey, 2016. Kuala Lumpur.

Eagly, A. H., \& Carli, L. L. (2007). Through the Labyrinth: The truth about how women become leaders. Boston: Harvard Business School Press.

Elder, S. (2010). Women in labour markets: Measuring progress and identifying challenges. International Labour Organization: Geneva.

Etzkowitz, H., Kemelgor, C., \& Uzzi, B. (2000). Athena Unbound: The Advancement of Women in Science and Technology. Cambridge: Cambridge University Press.

Faizli, A. A. (2017). Women: The key to a brighter Malaysia. Berita Astro Awani Online, Jan 11.

Fernandez, J. L. (2009). Intra-occupational gender earnings gaps in Malaysia. Jurnal Kemanusiaan, 14, 20-36.

Gibb, S. J., Ferguson, D. M., Horwood, L. J., \& Boden, J. M. (2013). The effects of parenthood on workforce participation and income for men and women. Journal of Family and Economic Issues, Feb, 1-13.

Grant Thornton International Business Report (2013). Grant Thornton: Chicago.

Hamel, S. (2009). Exit, voice and sense making following psychological contract violations. Journal of Business Communication, 46 (2), 234-261. 
INTERNATIONAL JOURNAL OF ACADEMIC RESEARCH IN BUSINESS AND SOCIAL SCIENCES

Vol. 10, No. 13, Special Issue: Upstream Research in Business and Management: Towards Socio-Economic Prosperity. 2020, E-ISSN: 2222-6990 @ 2020 HRMARS

Inglehart, R., \& Norris, P. (2003). Rising tide: Gender equality and cultural change around the world. New York: Cambridge University Press.

Izharuddin, A., Lee, C. A., Martin, D., \& Lee, F. (2013). Women's exodus from the workforce: Not just brain drain. The Malaysian Insider, June 12, 2013.

Jaber, M. A. (2017). Time to stop ignoring cultural barriers to female employment in the MENA region, Education Plus Development, September 11.

Kurshitashvili, N. (2018). Lifting legal barriers on women's employment: How it impacts Ukraine's logistics and transport sectors. The World Bank, January 12.

Lang, I. H. (2012). The myth of the ambition gap. Forbes, January 6.

Mainiero, L. A., \& Sullivan, S. E. (2006). The Opt-Out Revolt: Why people are leaving companies to create kaleidocope careers. California: Davies Black Publishing.

Merican, J., \& Ghani, S. (2017). Women in leadership positions: Where is Malaysia at? Leaderonomics, October 6.

Molina, J., \& Montuenga, V. (2009). The motherhood wage penalty in Spain. Journal of Family and Economic Issues, 30 (3), 237-251.

O'Dorchai, S. P. (2008). Do women gain or lose from becoming mothers? Brussels Economic Review, $51,243-268$.

Ismail, R., \& Jajri, I. (2012). Gender wage differentials and discrimination in Malaysian Labor Market. World Applied Sciences Journal, 19 (5), 719-728.

Iyem, C., Ozturk, D.G., Yıldız, F.Z. (2018). Clustering and Clustering Potential in TR 32 Regions Province, International Journal of Academic Research in Accounting, Finance and Management Sciences 8 (3): 336- 345.

Rosser, S. V. (2004). The Science Glass Ceiling: Academic Women Scientists and the Struggle to Succeed. New York: Routledge.

Sahid, N. Z., Noordin, S. A., \& Sani, M. K. J. A. (2018). Customer-Driven Business Information provision in Malaysian Government Agencies' Library. International Journal of Academic Research in Progressive Education and Development, 7(3), 137-149.

Schwanke, D. A. (2013). Barriers for women to positions of power: How societal and corporate structures, perceptions of leadership and discrimination restrict women's advancement to authority. Earth Common Journal, 3 (2), 1-2.

The World Bank. (2012). World Development Report 2012: Gender, Equality and Development. World Development Report. The International Bank for Reconstruction and Development/The World Bank: Washington DC

UNDP. (2010). Human Development Report 2010. United Nations

Wellington, S., Kropf, M. B., \& Gerkovich, P. R. (2003). What's holding women back? Harvard Business Review, 81 (6), 18-19.

What are obstacles to women in the global workforce? Global Network Perspectives, March 24, 2017.

Zimmerman, K. (2016). What gender barriers do millennial women face in the workplace? Forbes, August 18, 2016.

CHRYSOULA, P. (2014). Recording Literacy Practices of Monolingual and Bilingual Infants. Multilingual Academic Journal of Education and Social Sciences, 2(2), 86-113.

Samuel, R., Omar, R., \& Hassian, U. (2020). Barriers to Women's Advancement in the Malaysian Private Enterprises. International Journal of Academic Research in Business and Social Sciences, 
INTERNATIONAL JOURNAL OF ACADEMIC RESEARCH IN BUSINESS AND SOCIAL SCIENCES

Vol. 10, No. 13, Special Issue: Upstream Research in Business and Management: Towards Socio-Economic Prosperity. 2020, E-ISSN: 2222-6990 @ 2020 HRMARS

10(13), 1-9. 